\title{
We come in Peace! (Well, do they?): Human Communicative Fears in Films of an Extra-terrestrial Nature
}

\begin{abstract}
Extra-terrestrial beings always have the potential to alter 'the world as we know it.' Whenever they appear in film or television, there is a debate about the possibility that we have, as human beings, to communicate with them. Linguistics and semiotics become key elements in our attempt to bridge the cultural gap. Be it through mathematics, music or technological gadgets, these films only mimic the uncertainty that arises from all types of intercultural contact. The fear is always the misinterpretation that can turn a 'We come in peace' into a fully-fledged war.

This article starts from a general review of 138 films from the decade 2007-2017 to recognize the main points present in their narrative, which shows that hostile conflict remains the main theme. Then it provides an interpretive analysis of the films to describe the type of communication fears that exist in contemporary films, taking a special look at Avatar (Cameron, 2009), Arrival (Villeneuve, 2016) and District 9 (Blomkamp, 2009) as the main representations of our current understanding of communication difficulties. The humanization of extra-terrestrial beings to establish communication with them becomes an inverse representation of the dehumanization of the other, the enemy, as depicted by certain sectors of society and a few recently elected governments, with whom it is difficult to establish mechanisms of communication and dialogue.
\end{abstract}

* Our colleague and friend, Sergio, passed away in March 2020, whilst we were awaiting the referee response to this article. This publication serves to honour his memory.

\author{
Sergio Roncallo-Dow* \\ PhD en Filosofía \\ Facultad de Comunicación, \\ Universidad de La Sabana \\ Chía, Colombia \\ ำ orcid.org/0000-0002-9816-1288 \\ Google Scholar
}

Enrique Uribe-Jongbloed $\mathrm{PhD}$ en Estudios de Medios de Comunicación

Facultad de Comunicación SocialPeriodismo, Universidad Externado de Colombia. Bogotá, Colombia Correo electrónico:

enrique.uribe@uexternado.edu.co (1) orcid.org/0000-0002-9415-7628

Google Scholar

Daniel Aguilar-Rodríguez $\mathrm{PhD}$ en Sociología

Facultad de Comunicación SocialPeriodismo, Universidad Externado de Colombia. Bogotá, Colombia Correo electrónico:

daniel.aguilar@uexternado.edu.co ㄴ) orcid.org/0000-0002-2112-2504

Google Scholar

Recibido: junio 10 de 2019

Aprobado: octubrel 31 de 2020

Key words:

communication, extra-terrestrial films, otherness, aliens, sci-fi films. 


\section{¡Venimos en paz! (Bueno, ¿lo hacen?): Miedos comunicativos humanos en películas de naturaleza extraterrestre}

\section{Resumen}

Los seres extraterrestres siempre tienen el potencial de alterar "el mundo tal como lo conocemos". Cuando aparecen en el cine o la televisión, hay un debate sobre la posibilidad que tenemos, como seres humanos, de comunicarnos con ellos. La lingüística y la semiótica se convierten en elementos clave en nuestro intento de cerrar la brecha cultural. Ya sea a través de las matemáticas, la música o los dispositivos tecnológicos, estas películas solo imitan la incertidumbre que surge de todos los tipos de contacto intercultural. El temor es siempre la mala interpretación que puede convertir a un "Venimos en paz" en una guerra de pleno derecho.

Este artículo parte de una revisión general de 138 películas de la década 2007-2017 para reconocer los principales temas de su narrativa. Se señala que el conflicto hostil se mantiene como la principal temática. Así desarrolla un análisis interpretativo de las películas para describir los temores comunicativos de los filmes contemporáneos, prestando especial atención a las obras Avatar (Cameron, 2009), Arrival (Villeneuve, 2016) y District 9 (Blomkamp, 2009) como representaciones de nuestras dificultades comunicativas actuales. La humanización de los seres extraterrestres para establecer comunicación con ellos se convierte en una representación inversa de la deshumanización del otro, del enemigo, como lo muestran ciertos sectores de la sociedad y algunos gobiernos recientemente elegidos, con los cuales es difícil establecer mecanismos de comunicación y el diálogo.
Palabras clave:

comunicación, películas de extraterrestres, otredad, extranjeros, películas de ciencia ficción. 


\section{A Fascination....}

Plato (1997b) presents us in his Theaetetus a description of his fellow philosopher, Thales of Miletus, stating that

[...] they say that Thales was studying the stars, Theodorus, and gazing aloft, when he fell into a well; and a witty and amusing Thracian servant-girl made fun of him because, she said, he was wild to know about what was up in the sky but failed to see what was in front of him and under his feet (174a)

This idea, a recurring one in contemporary pop culture, exemplifies the fascination that the heavens have brought upon humans. The image of a philosopher walking around amazed at the celestial dome is but one of the references that may be found in antique philosophy. In The Republic (Plato, 1997a), Glaucon, one of the protagonists, states that 'astronomy compels the soul to look upward, leads things here to things there' (529a). The sky, in its immensity, has always arisen curiosity and fear, and humans have always believed to see phenomena ${ }^{1}$ in it, which we have been unable to explain, but which have started to become part of the way we see the world. There has been a belief according to which the gods descend from the skies, an idea that remains present in some contemporary prayers -i.e. Our Father, who art in Heaven ${ }^{2}$ - and which, slowly, has given rise to multiple theories, some of them considered as pseudoscience — such as the Ancient Astronauts-, which states that the gods are nothing but misinterpreted aliens (Miller, 2017; Von Däniken, 2016). This is an idea that has continued into our days (Schofield Clark, 2005). Of course, these gods come riding chariots we have called UFOs and which have been, throughout history, objects of fear and fascination because we are certain we have seen them, yet we fail to understand the what and how of their appearance (Jung, 2002; Moffitt, 2006; Scolari, 2005). Interestingly, curiosity has seemed to be stronger than fear.

Dengo (2012) also informs us that, 


\begin{abstract}
Whenever you look for information on the NASA website, the field that includes the author of a Discovery reads "Known by the ancient." As opposed to Neptune and former-planet Pluto, Mars has always been a part of our understanding of the solar system.
\end{abstract}

It is easy to spot, Mars is visible to the naked eye and it is clearly red. It is also close: our possibility to see it bears witness to the relative closeness of the planet.

Pop culture is laden with references to Mars: films with names such as Mission to Mars (2000) and Red Planet (2000), documentaries such as Can we make it to Mars? by NOVA, without going through the large number of science fiction stories such as The Martian Chronicles by Ray Bradbury from the 1950s and non-fiction books such as The Case for Mars and, obviously, Packing for Mars, which revolve around the requirements to send, not only an analog robot, but a person to the planet. [Our translation]

If there is a trait that seems to define humanity, it is curiosity, a searching after the unknown that, alongside fear, exerts a strange fascination (Bohlmann and Bürger, 2018). In fact, the Mars Science Laboratory, a mission to Mars launched on November 26, 2011, is also known as Curiosity. Fascination is evident on the scientific field, but it is equally present in pop culture - and maybe even more in the latter-. Since the 1950s we could make a long list of mediatized alien invasions in film, television and videogames (Amis, 2015; Martos-Nuñez and Martos-García, 2015; Pincio, 2009; Scolari, 2005) and some real ones, such as the one in Rosswell ${ }^{3}$ that have filtered through the sensibility of Western culture (Moffitt, 2006; Moulton Howe, 2016; Roncallo-Dow et al., 2016). Maybe one of the places where this fascination has taken hold is precisely in audiovisual products —namely film and TV series_-, where we have recreated our own version of what aliens are - or should be- like.

From the Selenites of $A$ Trip to the Moon (Méliès, 1902) to the octopus-like cephalopods Abbot and Costello in Arrival (Villeneuve, 2016), we seem to be obsessed with including aliens as part of our films. No less than 130 films in the last 10 years seem to include, in one way or another, extra-terrestrial beings (see IMDb, 2018). We grant them everything from the manic compulsion to kill 
as part of their survival instinct or feeding habits —as in Alien (Scott, 1979) and all its prequels and sequels, or in the cases of Critters (Herek, 1986) or Killer clowns from outer space (Chiodo, 1988) — or as conscious races willing to wipe us from the face of the earth, whether by taking over our planet —as is the case of Independence Day (Emmerich, 1996), War of the Worlds (Haskin, 1953) and Mars Attacks! (Burton, 1996) — or perhaps by warning us of a possible demise —in The Day the Earth Stood Still (Wise, 1951) or even Arrival (Villeneuve, 2016).

Whatever intentions we assign to them, we approach them with suspicion, at the very best. There is no way an extra-terrestrial entity would have made it to us if it did not have at least some clear intentions about what to do with us. Namely, our approach to dealing with aliens seems to say a lot about our own intentions and where we stand at the other end of the story. In a sense, we seem to only be looking at a mirror when we explore the creatures from beyond the vast expanses of space. Whether 'because of budgetary constraints or for reasons of anthropocentrism' (Rutherford, 2017, p. 169), there seems to be a great deal of films in which our extra-terrestrial counterparts are not very different from ourselves (Scolari, 2005). However, despite the often-displayed visual similitude, extra-terrestrial beings might harbour all sorts of ideas about us. In other words, they surely are up to something; and that something is surely not good at all.

Not always do we look the same. The likes of Jerome Newton and Mr. Spock might get the occasional glance at a local high school reunion in the 1960s, particularly because of their speech patterns, but they are certainly not very anatomically surprising. Insect-like beings, such as those from Starship Troopers (Verhoeven, 1997) or District 9 (Blomkamp, 2009), and repulsively elongated and phallic figures, like the Xenomorph of the Alien saga (Various directors, 1979-2017) —or their seemingly not-so-distant British cousin in Split Second (Maylam, 1992) — they all share a certain resemblance to earthy 
creatures (Rutherford, 2017). Both in real scientific pursuit of extra-terrestrial beings (Cabrol, 2017) and in our own filmic imagination of the creatures, we are bound by the idea that we are searching for life as we know it. This is an entirely understandable perspective, for it certainly is much easier to imagine a creature similar to one we already know than something completely different from it. Quite simply, because making it completely different begs for the question of how does one frame the notions of 'completely' and 'different'.

In less than a century, aliens invaded earth in every possible way and through as many diverse means. Initial fear became fascination and fascination turned into merchandise. From the B-movies of the 1950s Hollywood industry, aliens became the inhabitants of the Third World - a name also given to the place where the Thundercats (Wolf, 1985) lived - and they colonized the most important ground to ensure their dominion, the collective imagination. Nowadays, we face all sorts of (conspiracy) theories that suggest that we might even be the folly of an alien experiment. That is the case of the writings of Erich Von Däniken (1968) and his mediatization in series such as Ancient Aliens (Burns, 2009), which have spurred theories and experts on the alien phenomenon that seems to be similar to earthlings. Around 2012, when the end of the world was expected to be nigh - according to the Mayan prophecies - there were many voices claiming the return or invasion of aliens. The colonization of the imaginary runs deep and provides an interesting point of departure for the functionalist concepts of the mid-twentieth century. What links films like The Flying Saucer (Conrad, 1950) and District 9 (Blomkamp, 2009)? The question brings back old and recent media depictions of aliens: in the former film, aliens are communists, and in the latter, they are the marginalized, the disenfranchised, the segregated. They are built as the other from our hegemonic semiotic construction, in our own likeliness, as the reflection of our current fears. 
Extra-terrestrials, thus, seem to be usually closer to types of life we are familiar with, as the famous misquoted phrase from Mr. Spock would suggest 'It's life, Jim, but not as we know it.' In other words, our characters in extra-terrestrial films tend to have enough recognizable elements for us to be able to approach them. There is a caveat here. Although they may resemble us - and even worse so when they do not-, we seem to be at odds in trying to communicate with these other-worldly beings. Films often skip the complexity of linguistic interaction and simplify what would certainly be the most difficult exchange between two sentient and technologically developed species. Many movies reduce linguistics in the symbolic economy of the film and often enough a technological device manages to bridge the communication gap through assuming the common biological similitude can account for the linguistic closeness. Clearly, this has to do with the fact that if they were not similar to anything we already seemed to know, we would wonder how on earth could we communicate with them. As the turn of the phrase used here seems to already present to us, our own earthly domain sets the ground for this first worrisome encounter.

\section{An approach to the communicational problems with aliens in contemporary films}

To answer the question of our current communication fears, this article presents a qualitative research process from a universe of 514 alien-related movies produced between 1902 and 2017. We narrowed down the sample to 138 feature-length films of a variety of genres (comedy, sci-fi, action) produced between 2007 and 2017 (see Table 1) and whose information was available on the Internet Movie Database (IMDb). It was unsurprising, yet important, that 112 of the films were produced in the USA and from a Western -particularly American- perspective, highlighting such fact. 
We focused on how the question of engaging with or approaching the extraterrestrial beings was dealt with. These films were analysed under three categories: a) Relation to humanity [Main topic]; b) Alien Characters [Hostile Alien Life Form; Friendly Alien Life Form; Body Snatcher; Alien Life Form; Unknown Alien Force; Humanoids; Human-Like; All sorts of Alien Life Forms] and, C) Type of communication between humans and aliens [No interaction; Interaction; Conflict; Interaction - Conflict] (see Table 1).

Our purpose was to understand the metaphors of the relationship with the alien other, from a communicative perspective. Out of the 138 films in the sample, 135 provided enough information for the categories established, while 3 proved rather difficult to classify. It became clear that conflict with hostile alien life forms $(n=40)$ remains the main topic when addressing our communications with aliens, followed by interaction-conflict with human-like creatures $(n=10)$ as the second most common theme (see Figure 1). Only the first six connections between type of communication and alien characters yielded at least 2 films, whereas the others only yielded 1 film each - and were thus not considered relevant-. 


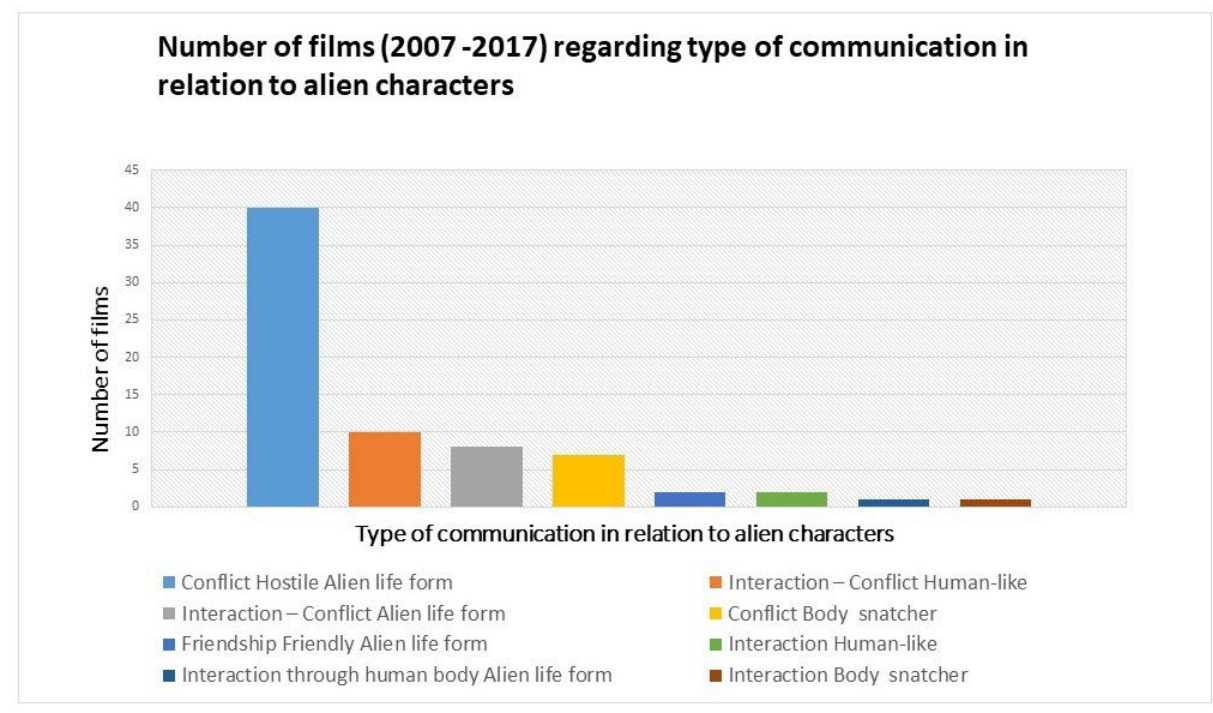

Figure 1. Number of films (2007-2017) regarding type of communication. Source: Compiled by authors.

Starting from this quantitative perspective, we opted for a cultural analysis of what we consider to be the main themes. If conflict with hostile alien forms is the key topic, how is that presented and what does it tell us about how we, as human beings, communicate?

Drawing from philosophical debates, cultural studies and linguistics, and presenting examples that span over the 514 films, communication fears are presented in their evolution - not in a sense of improvement, but rather as change over time- in how they exemplify the different fears in terms of communication. Special attention is given to three contemporary films within the sample, namely Arrival (Villeneuve, 2016), District 9 (Blomkamp, 2009) and Avatar (Cameron, 2009), although other films, including the Alien saga, 
which expands from 1979 to 2017 (Scott, 1979; 2017; Cameron, 1986; Fincher, 1992; Jeunet, 1997; Anderson, 2004) and the Star Trek reboot (Abrams, 2009; 2013; Lin, 2016), and their characters are also often mentioned. Our approach is hermeneutical and creates links between the times and the themes in order to coalesce in a fluid narrative.

\section{If We cannot communicate with Them, do They come in Peace?}

As explained by Peters (1999 sec. Communication with Aliens), the idea of communication with aliens, although always present, is empirically anchored to the late nineteenth century, in the sense that the advent of modernity, heralded by Marx, Feuerbach, Nietzsche and Freud, tried to free human imagination from fantastic beings such as gods, demons and angels. Following that train of thought, 'science has compensated by seeking contact with objective others-animals, aliens, 'primitives', the unconscious. In research on extra-terrestrial intelligence, as on animal communication, all kinds of strategies have been sought to transcend the inevitability of one-way communication' (Peters 1999, sec. Communication with Aliens). Of course, in relatively scientific terms, communication with aliens may face a different problem: temporal dislocation (Hacyan, 2014; Peters, 1999). A project like SETI could reveal that, for instance, any attempt to communicate with alien entities through radio waves —as attempted by Frank Drake in the 1960s — would imply thinking of an asymmetric time frame between transmission and reception: a message sent to a nearby galaxy, like Andromeda, which is 2,537 million light years away, would take very long to reach us.

Interstellar communication is riddled with astronomical gaps: mind-numbing distances, ranging from four light-years to billions; delays between call and response that could outlast a thousand earth generations; the problem of signal persistence through Doppler shifts, space-time distortion, and signal scatter caused by cosmic dust and gases; and the prospect of such a radical otherness in our interlocutors that their math, their being in time, or their bodies might be like nothing in our ken. Their strangeness could put all other strangeness to shame (Peters, 1999, sec. Communication with Aliens) 
Peters (1999) then goes on to remind us that beyond time asymmetry, other issues may arise in communication with aliens. To imagine a life form, as already addressed by Wittgenstein (2009), is to imagine a whole new life form. If language games are what provide us with family resemblance, we would have to accept that aliens are within that set of similitudes. This would imply that any form of alien language and any form of alien communication must have patterns that strike us as familiar to our own languages. Even a film like Arrival (Villeneuve, 2016) escapes the linguistic relativism of Sapir-Whorf, which presupposes the impossibility of language universality, that is, worldviews as language dependent (Deutscher, 2010; Mayer, 2017; Sutton, 2018).

In many cases, while highlighting our extremely Cartesian view of reality, it has been assumed that mathematics — in their anthropocentric version - are the universal language (Cocconi and Morrison, 1959) and that aliens would hold a vision of the world supported in similar pillars as our concept of colour (Narusawa, et al., 2018) or that they would also enjoy similar behavioural aspects such as ethics and morals (Peters, 2018; Szendy, 2013). This incessant search for similarities is what gets ripped to shreds in films like Annihilation (Garland, 2018), where ontological certainties taken from the scientific discourse of biology disappear in the Shimmer, a quarantine ward where an alien presence seems to have altered life's own logic. Thus, there has been a lot of discussion about the scientific footing of many alien fictions (Kirby, 2003).

Extra-terrestrial films have managed to exploit one of the inherent fears of humanity regardless of the different forms of social organization we have developed: fear of the other, the different, the abnormal. It has exposed the absolute terror of the one who does not only resemble us - to the extent previously described-, but who also reminds us of the things we have grown up thinking and being educated to fear, to assume as the opposite, as a threat, as an enemy. 
For Michel Foucault (2002), this fear of the other appears in the form of racism in modern societies that work within the modality of bio-power. Fear emerges, because the political enemy (ideological opposite) is extrapolated to the biological enemy, which is based on racial or ethnic differences (Wagner, 2015; Pheasant-Kelly, 2016). In the case of science fiction films that base their plot on the possible arrival of life forms from other planets, the fear of colonization appears. The panic generated by their unknown power and the possibility to become victims of what every colonizing process has brought with it: genocide. This is the fear of our own Western genocide of indigenous peoples, and many films _including Avatar (Cameron, 2010)_ exemplify this fear (Veracini, 2011).

The classic writer of supernatural horror, H.P. Lovecraft, began his 1927 essay on this genre by stating that 'the oldest and strongest emotion of mankind is fear, and the oldest and strongest kind of fear is fear of the unknown' (para. 1). This phrase summarizes our inherent fear towards those who might exist beyond our grasp, our comprehension, and, in a way, our control. Lacan mentioned how we develop knowledge as a weapon to overcome our paranoid fear of the unknown, since 'the other, and particularly the other's desire, is always a potential threat to the subject because it is an alien force that stands in firm opposition to the subject, an antithesis that evokes rivalry and competition' (Mills, 2003, p. 37, our italics). Taking that to another level, we can imagine that our collective imagination of the encounters with potential extra-terrestrial beings can be understood as our own fear of ourselves. A fear that, of course, entails a fear of the other; this other that we recognize, not as an other, but as a de-formed version of ourselves. Think about the extra-terrestrial creatures in District 9 referred to as 'prawns', which end up living in slums in Johannesburg. 
They are seen chopping up cows' heads in an establishing vignette, which is framed along with similar impressions (aliens rummaging through garbage, or fighting over junk) that seem angled to communicate a repulsive vulgarity ... The Prawns, then, seem to be not quite fully universal signifiers of otherness, but rather doppelgangers of the black working class or poor shack dwellers who feature marginally in the film without being brought into the limelight. (Van Veuren, 2012, p. 574).

This example shows how these films tend to draw attention to aspects of our own humanity, the realities we see every day, the fears of our own interaction with other human beings. Thus, in all those films, 'the aim of the stories often is to reflect on our own morality' (Kracher, 2006, 331).

Two ideas come into play. On the one hand, there is reciprocity and recognition of the other. Maybe the problem of understanding an alien is precisely that: the impossibility of recognition. Reciprocity demands the idea of a two-way correspondence with the other person —or entity, in our case-, as suggested by the Latin etymology of the Word reciprocitas, from which reciprocity stems. Now, this idea of correspondence implies the need of a relationship with the other — which in itself implies an alterity - in terms of a common existence written in the ' $\mathrm{Co}^{\prime}$ ' suffix of correspondence. In its more common sense, mutuality could be understood as very close to and almost synonym to reciprocity: after all, whatever is mutual is something that belongs to us, what we share, what we call our own. Along these lines, Paul Ricoeur (2005) warns us that we should understand mutuality to be the most intimate form of reciprocity.

Ricoeur (2005) uses the Greek term allelon, which could be translated as 'for one another'. This Greek word used by Ricoeur suggests, on the one hand, a closeness between reciprocity and mutuality, as presented also in the translation of the term into English in the Lidell-Scott dictionary: one another, reciprocally, mutually. On the other hand, and this could become the central issue here, beyond translation or any explanation of the Greek word to clarify 
the sense of mutuality, the relationship between one and other is surrounded by a deep asymmetry that opposes reciprocity, 'the insurmountable difference that prevents one from the other in the core of the alleloi, from "one another"' (2005, p. 152).

The renowned phrase 'we are not alone' turns into some sort of omen that strengthens the fear generated in the event of the possible arrival and colonization of the planet earth by extra-terrestrial beings that are completely unknown to us and whose powers we do not know. Others whose superiority over humanity has been assumed and become one of the most recurrent discourses of the so-called science fiction cinema and is manifested, not only by its unknown technologies that allow them to travel through space or even time, but also because they do not count with specific key (moral) elements that define forms of social control, fundamental norms to configure the social order.

Ash: You still do not understand what you're dealing with, do you? Perfect organism. Its structural perfection is matched only by its hostility.

Lambert: You admire it.

Ash: I admire its purity. A survivor ... unclouded by conscience, remorse, or delusions of morality. (Scott, 2011[1979])

A determinant aspect in the configuration of the extra-terrestrial alien is the fact of conceiving it as something difficult to define or describe (almost an object), particularly if it is an alien form whose physical and biological characteristics are far from human resemblance. Creatures that constitute greater danger when their organism represents something unknown and incomparable with the human body, or whose greater threat represents the possibility of colonizing, not the planet, but the human organism. The more the extra-terrestrial looks like a human, the more respectable, and the less feared since they are assumed to be able of communication. That is the reason why, on the one hand, characters such as Mr. Spock in Star Trek represented some sort of security for humans 
who worked with him. He did not represent a threat to humanity or the human lifestyle -Mr. Spock, in fact, is easy recognizable-, despite his obvious different behaviour. On the other hand, a character such as the alien organism in The Thing (1982), which colonized human beings, or the life form in Alien (1979) and all its iterations, represented that unidentified organism whose only purpose is to destroy humans.

The gap created with the second type of aliens, due to their biological characteristics inevitably generate greater resistance, because it is not possible to establish dialogue with them, from a human communication perspective. The only way to know about their intention and to interpret their emotions and thoughts depends on reading certain behaviours from a human point of view, in the same ways we do with animals. Nevertheless, the difference lies in thousands of years of domestication and imposition of the human will upon the animal kingdom, compared to the ignorance regarding extra-terrestrial life forms.

I dunno what the hell's in there, but it's weird and pissed off, whatever it is.

(Carpenter, 1982)

Given the above, the fundamental basis of fear reduction lies in the possibility of reducing the distance between humans and aliens, as long as it is possible to establish contact as interlocutors. This necessarily implies the need to humanize the other, the stranger. It implies finding common elements that allow the exchange of ideas, which, in turn, means bringing that different being, into the same symbolic context and meanings.

\footnotetext{
Dr. Collins: I think we should try to make them understand we mean them no harm. They are living creatures out there.

Sylvia: But they're not human. Dr. Forrester says they're some kind of advanced civilization.

Dr. Collins: If they're more advanced than us, they should be nearer the creator for that reason. No real attempt has been made to communicate with them, do you know? (Haskin, 1953)
} 
There are several stories regarding the other, narrative constructions that assume "realities" and are based on observations and testimonies, as empirical evidence, that become prejudices from which it is believed to know that other. By means of these discourses the other is constructed, the different, the 'incorrigibly contrary' (Merton, 2002, p. 508) that becomes an external ethnic group. Thus, the construction of the alien imaginary and the visual narratives that are built around it, pose two scenarios that start from the fear of the other. In the first place, the fear of one with whom biological similarities are not shared, which immediately is assumed as communicative impossibilities and leads to conflict. Second scenario, those beings whose proximity in their physical appearance denotes an anthropomorphism, as a hope, that involves the possibility of establishing a contact that results in a peaceful victory on the part of the human race.

For all of the above, the different, the alien (both extra-terrestrial and earthlings) ends up being represented through narratives that are assumed as true, exoticised, thus giving reason to Thomas (2005) theorem, who pointed out that if individuals define situations as real, these are real in their consequences. The narratives told and the stories written regarding aliens and the possibility of contact with them explain the event of October 30, 1938, when the North American radio audiences assumed as real such an invasion and behaved accordingly with the imaginary they had about it. However, by then, the developing film industry had not advanced yet Science Fiction and Alien stories as a genre.

The films in which the question regarding communication appears raise the possibility of contact with the aliens at the moment in which common elements are found and allow the configuration of a system of signs end the exchange of ideas, the dialogue and the interpellation. A linguistic and sign system that allow the representation of the world and its different realities. 
It implies reaching consensus around the world and life, which in turn allow negotiation before a possible alien invasion and the destruction of the world as we know it.'

In films where the alien becomes that biological enemy, it threatens not only the status quo, whether based on race or ethnicity, but human existence or freedom, and then the possibility of communication with the other is null, impossible, or displaced onto another space of less importance. It is, precisely in those spaces in which the warlike confrontation between the worlds is inevitable. A negotiated exit to the conflict disappears and only the confrontation remains, which, in addition, occurs in conditions of superiority of the Alien, but it inevitably changes in favour of human beings who impose their linguistic and symbolic system, impose the other its world and its norms.

When dealing with aliens, try to be polite, but firm. And always remember that a smile is cheaper than a bullet. [Instructional voice]

(Blomkamp, 2009)

From this perspective, the extra-terrestrial alien is demanded the assimilation that is also demanded from the foreigner, otherwise, its presence alters the functioning of the social system as it is organized. Therefore, the other is destined to assimilate, surrender, exclude, be expelled from the planet or die in its attempt to colonize. For Merton (2002), ethnic tolerance becomes a "benevolent form of domination" by what he calls the dominant intragroup - those subjects that belong to the dominant group and the receiving environment-, and which aims to achieve the stabilization of the social system. In this way, not only the rules and laws, but the discourses and narratives that are assumed true and that deepen the gap, in this particular case, with that extra-terrestrial being, opposite, that must submit to our rules, our ways. In short, our world. 
Van de Merwe: We need your signature on this eviction notice

Alien: Fuck off!

(Blomkamp, 2009)

Thus, the humanization of the extra-terrestrial becomes a need, in order to confer characteristics that allow the encounter and the dialogue, to avoid confrontation and, likewise, the domination of the invader by imposing on it the new system of understanding and interpreting the world. This is the opposite to what happens in real life, where the biological enemy in terms of race, or the political enemy in ideological or religious terms is removed from his condition as a human being, as a subject, and becomes an object, which is pushed towards its otherness, emphasizing the existing differences, or what Merton (2002) defined as an 'Incorrigible contrary.' An opposed other with which any form of negotiation is impossible - this also applies to feminist women, homosexuals, ethnic groups and racial others. Bear in mind, for instance, that in most films that include the abduction of human beings, they are always representatives of the white American population, rarely including African-Americans, or even less so, Asian Americans (Tromly, 2017). Tromly even goes on to state that

\footnotetext{
There are two reasons an Asian American presence is untenable in the discourse of alien abduction, one that hinges on characteristics attributed to Asian Americans and another that emerges from suspicions about the coherence of the very idea of an Asian American. First, the radical difference in appearance, culture, and language frequently ascribed to Asian Americans puts the figure of the Asian American abductee in an intermediate position between alien captor and human captive. In other words, Asian American identity seems to blur the species difference central to the abduction narrative. (p. 287)
}

In other words, non-white Americans are already different enough in their own right, that they cannot be easily associated with the human 'norm' in opposition to the alien 'otherness'. 
Here we could go back to Lévinas (1993) classic proposals and to an approach to the idea of living together, understood as mutuality, and the role he grants to the face as intimately linked to the other. In fact, it is precisely the face of another person what Lévinas defines as the 'sense's place of origin' (1993, 174). It would seem that it is precisely the face, in the conquest of exteriority, which lays claims upon our place in the world —or the universe.

At this stage, it becomes relevant to begin an etymological exercise about the word 'face' from its French origin in 'visage'. The word 'visage', like its Italian counterpart 'viso', finds its origin in the Latin verbs 'vistare' and 'videre', particularly in the indicative present: 'visito' and 'video'. Now, 'visito' stems from the semantic trunk 'viso', the indicative present of 'visere' translated by Lewis \& Short, as 'to look at attentively, view, behold, survey.' From a simple approach, 'visitar' - to visit- is "to go and see someone as a courtesy, attention, friendship or any other motivation." This is exactly the same as the compound verb 'ymweld' — to visit— in Welsh, which brings together ' $y m^{\prime}$ —in or along— and 'gweld' — to see—.

Then, to visit is actually to go and see, it is a movement towards the other in a double attitude. We place that 'face' before us in an egocentric turn, as al alter, in a dimension close to Husserl's. The idea of the 'visit' presupposes a way of reaching out to the other, to go 'see a person at home', to get close to their 'place under the sun' (Lévinas, 1993). The aliens come to visit, but we fail to see their face, and thus recognize them.

\section{Linguistic simplification}

Extra-terrestrial beings seem to be able to cope with our environment rather easily, either through the use of helmets, or some rather mysterious ways of blending in with our own atmospheric conditions. They are usually able to 
communicate, and more often than expected their communication properties resemble our own; speech is the privileged form of communication, rather than sign language, haptics or something between them. In many films, the question of translatability is often sidestepped diegetically by means of technological gadgets (Star Trek; Mars Attacks!), genetically-based consciousness (District 9) or even interstellar creatures capable of direct translation — such as the Babel Fish (Hitchhiker's guide to the Galaxy). Extra diegetically, these languages are translated often for the audience through subtitles, which explain what the characters seem to be saying, in the same way that the above discussion presented regarding the physical similitude of the aliens, since

contact stories have given us the 'scripts' to imagine approaches to the unknown, but we must imagine it through the prism of our own experience, and thus the stories will always be contaminated with human language, even when they pretend to translate alien thought. (Washbourne, 2015, p. 15)

Thus, most alien languages resemble many of our own characteristics, and actually put the contrast of the given language to our own in similar political structures to languages already in existence. Whereas the Klingon's language is a guttural language similar to Hebrew — with sufficient otherness to most Westerners-, the language of the extra-terrestrial "prawns" in District 9 resembles many of the characteristics of San, Khoi, isiXhosa or isiZulu (Veracini, 2011, p. 359). In both cases their 'foreign' sound to specific ears tries to account for their otherness, thus equating already existing linguistic stereotypes that generalise otherness in relation to distance from English. Similarly, benevolent or friendly foreign encounters almost always come with linguistic creations that try to sound softer to our ears, and associated positively, such as the case of Avatar where 'the language of the Na'vi ... is a dignified and sophisticated constructed 'indigenous' language' (Veracini, 2011, p. 359).

Basically, upon entering a dialogue with an extra-terrestrial being 'untranslatability is either ideologically dramatized as a first contact with insurmountable or 
unconquerable otherness or surmounted and conquered though manipulation or through colonializing assertions of a de facto universality' (Washbourne, 2015, p. 2). These two options seem to go hand in hand with the opposing discourses of seeing the extra-terrestrial aliens as impossible to comprehend, and thus impossible to translate - becoming the ultimate other that can only co-exist in parallel, but never in tandem with human beings - or it renders linguistic difference as easily overtaken by supposedly universal elements that, in a certain way, grant direct status to English as sufficient form of communication in a very ethnocentric way. Sitting right in the middle of this perspective is the repetitive translation of the Martians in Mars Attacks! which, based on technological reassurance and translating simplicity, manage to present a message that is either consciously or unintendedly opposite to the actual actions performed.

Language becomes a proxy for all possibility of communication. Extra-terrestrial creatures learn our languages —as in the case of E.T. (Spielberg, 1982) — with apparent ease. Some of them even speak it without any possible explanation regarding why they do so, as the modern Shakespearean spoken by Thor in the movie of the same name (Branagh, 2011) or the furry extra-terrestrial Alf (Patchett and Fusco, 1986), limiting the linguistic difference to the naming of particular animals or places — which are easily pronounceable in English. Similarly, the names of extra-terrestrial superheroes are easily pronounceable in modern day English - the furry giant Chewbacca in the Star Wars movies has a name that is unpronounceable in its own language, for instance-, even if they sound unfamiliar, and replicate the situation of their comic counterparts which comply with the following pattern of the comics of the Silver Age:

- $\quad$ First name + family name construction

- Pronounceable by speakers of English - orthography does not indicate any sounds not found in US English (e.g., clicks, implosives, uvular or glottal fricatives)

- Syllable count and consonant choices indicate male and female categories of names. (Sutton, 2016, p. 112) 
Of course, the idea to make aliens either intelligible or unintelligible provides narrative elements because they can enter discussions lightly or render them impossible. The ethnocentric linguistic ideology permeates films by making the need for English as a lingua franca, a given, not only in the dialogue with the audience, but also as an expected language that any extra-terrestrial being would learn in order to communicate with earthlings. English is the natural language of aliens because there is an assumption that they would learn the language of the dominant elite of the Earth, and that is, from the perspective of most Hollywood film-makers, the language of the US. Little do they seem to realize that the US has considerable minorities who speak a variety of different languages, including Spanish, Chinese and Hindi, which are spoken by considerably more people world-wide.

\section{Conclusion: What do these films tell us, then?}

Reflection upon those extra-terrestrial encounters in films turn to serve a scrutiny of our own Western fear of difference, inability to communicate and impossibility to comprehend the world in a different way. However, what it brings is an actual misunderstanding of our own human existence, our own guilt, racism and lack of reciprocity. The situation is clear in many different films and narratives of alien encounters. For instance,

Men in Black represents the illegal alien as Indian in a number of ways, including language (like the alien, many Latin-American Indians do not speak Spanish as their first language or at all), the reference to treaties and the alien's previously described long hair and 'Indian' costume. Such associations are reinforced when the alien menacingly extends a halo of feather-like flippers around his head that resembles a Plains Indian war bonnet. (Marez, 2004, p.348)

Thus, it becomes useful to look at those films to understand our own human limitations, the current fears of Western civilization, and 'we need to listen to the aliens we have created. It may be that aliens do not exist, but they 
do not have to be real in order for the moral lessons to be real' (Kracher, 2006, p. 344). For scientists as well as filmmakers, 'the more we look [for extra-terrestrial life], the more we find out about ourselves, both in science and science fiction' (Rutherford, 2016, p.177). The alien is no other, it is a look into our own discomforts, a mirror, evidence of our own communication failure.

Of course, we need to admit here that we are addressing the dominant discourse of Hollywood films and television shows, which has remained strong despite possible contra-flows of media production with 112 of the selected 138 films of the decade 2007-2017 (see Table 1). The fears portrayed in those films are the fears of the US and, maybe, by extension, those of the whole Western world, because

it remains an undeniable fact that the products of the United States are, whether modified or not universally popular ... [but] there is a debate to be had as whether this popularity is a recognition of their intrinsic merit or merely of the economic and political supremacy of the nation that creates them. (Crisell, 2006, p.151).

In that respect, 'Hollywood sci-fi films ... project Western desires and anxieties regarding colonization, self-destruction, and Euro-typical utopiadystopias' (Lempert, 2014, p.165), and the function of some of its films is to try to address a sense of guilt upon its own cultural genocides, as is evident in Avatar (Cameron 2009) or our own desire of retaliation and conquest by force, as in Ender's Game (Hood, 2013). Non-Western stories of contact, like those found in indigenous and native science fiction films, 'challenge naturalized Eurocentric ideas regarding which societies are best positioned to serve as interplanetary cultural ambassadors' (Lempert, 2014, p.166). Lempert does make a point of trying to understand these indigenous and native sci-fi films as concerned with different issues regarding communicating with extra-terrestrial beings. Accordingly, communication with aliens is, basically, a debate of intercultural communication, and Hollywood films are the Western perspective of those fears. 
Hellstrand (2016) argues that there are three ways in which late sci-fi has embodied discussions of the other and the representation ontologies described within it. The first one is for that other, be it a robot or an extra-terrestrial being, to conform to the hegemonic and normalizing discourses, thus exposing the regulatory frames at stake in the delimitation of human ontology, and brings to fore mechanisms of exclusion and inclusion, of sameness and difference, that operate as the norms of intelligibility for the human subject.' (263). The second one is by creating a sense of uncertainty of what could be human, yet it is regarded as ontologically debatable, mostly present in partly human creatures — such as Mr. Spock or other alien-human hybrids_. And the third 'trajectory confronts the hegemonic position of human ontology, and addresses the conditions of possibility for non-human agency' (264). Those three trajectories seem to match perfectly well with notions of purity, hybridity and difference often found in political discourses of race and ethnicity that establish the limits of communication among human groups.

Lempert (2014) and Hellstrand (2016) basically present us with the central discussions about extra-terrestrial films as centred on our own hegemonic Western perspective of communication and the possibility —or impossibilityof intercultural communication within it.

In those films and television series, 'the world as we know it' represents the concern regarding the stability of our system. A system of social organization that works, in one way or another, with inequalities, but which has very clear foundational bases set in a fear of difference and joy of homogeny. From those perspectives, the others who do not look like us and whose expectations and behaviours do not match our culturally prescribed aspirations become anomalies that, in turn, realize that the stability of the system is secured at the expense of social flexibility. The less flexible and close to otherness, the more stable. Stability is found in homogeneity, in a very radical xenophobic 
and culturally insensitive discourse. Most analyses of extra-terrestrial films indicate this issue, whether in movies of invasion as Independence Day (Emmerich, 1996), interstellar war as in Starship Troopers (Verhoeven, 1997) or extra-terrestrial refugees, as in District 9 (Blomkamp, 2009), including E.T. (Spielberg, 1982). Intercultural communication remains the central discussion of extra-terrestrial films. What those films set to represent is our ability to understand the world in which we live. Similar to the debate by scientists, who look for life in other worlds akin to our own concept of life, audiovisual creators show the struggles of our relationship with aliens delving deep in our own fears and guilt of our cultural colonization practices.

Thus, based on the enormous generation of Hollywood narratives about the other, especially the extra-terrestrial alien, and the possibility of a real arrival of these on our planet, very surely, we would be waiting for them in the depths of our fears. We will expect to see them descending from their spacecraft and raising their hands, hopefully with five digits in each one, greeting us and saying in perfect American English 'we come in peace.'

\section{References}

Anderson, P. W. S. (Director). (2004). AVP: Alien vs. Predator [Movie]. Twentieth Century Fox.

Amis, M. (2015). La invasión de los marcianitos [The invasion of the martians]. Malpaso.

Blomkamp, N. (Director). (2009). District 9 [Movie]. WingNut Films.

Bohlmann, U. M., \& Bürger, M. J. (2018). Anthropomorphism in the search for extra-terrestrial intelligence-The limits of cognition?. ActaAstronautica, 143, 163-168.https://doi.org/10.1016/j.actaastro.2017.11.033. 
Boyington, P. (Director). (1990). Hangar 18. Megadeath (Artist) [Music Video]. 6 min $28 \mathrm{sec}$. USA.

Burns, K. (Producer). (2009). Ancient Aliens. [TV series]. A\&E Television Networks

Burton, T. (Director). (1996). Mars Attacks! [Movie]. Warner Bros.

Cabrol, N. (2017). "What are we looking for? An overview of the search for extraterrestrials." In Aliens. The world's leading scientists on the search for extraterrestrial life, Al-Khalili, J. (Ed.) pp.178-87. Picador.

Cameron, J. (Director). (2009). Avatar [BluRay]. 20th Century Fox.

Chiodo, S. (Director). (1988). Killer clowns from outer space [Movie]. Media Home Entertainment.

Cocconi, G, \& Morrison, P. (1959). Searching for interstellar communications. Nature 184, 844-46. https://doi.org/10.1038/184844a0

Conrad, M. (Producer and Director). (1950). The flying saucer [Movie]. Colonial Productions, Inc.

Crisell, A. (2006). A study of modern television. Palgrave Macmillan.

Dengo, S. (2012, Aug, 12). El porqué de la fascinación de los terrícolas con Marte. [The why of human fascination with Mars]. Expansión Revista electrónica. https://expansion.mx/tecnologia/2012/08/07/marte-el-planetavecino-que-nos-produce-fascinacion

Deutscher, G. (2010). Through the language glass. Why the world looks different in other languages. Metropolitan Books.

Emmeric, R. (Director). (1996). Independence Day [Movie]. Centropolis Entertainment.

Branagh, K. (Director). (2011). Thor [Movie]. Marvel. 
Carpenter, J. (Director). (1982). The Thing [Movie]. Universal Pictures

Foucault, M. (2002). Defender la Sociedad. [Defending Society]. Fondo de Cultura Económica.

Garland, A. (Director). 2018. Annihilation [Movie]. Skydance Productions.

Hacyan, S. (2014). Ovnis y viajes interestelares, ¿realidad o fantasía? [UFOs and interstellar travel, reality or fiction?] Fondo de Cultura Económica.

Haskin, B. (Director). 1953. The War of the Worlds [Movie]. Paramount Pictures.

Herek, S. (Director). (1986). Critters [Movie]. New Line Cinema.

Hood, G. (Director). (2013). Ender's Game [Movie]. Oddlot Entertainment.

Jennings, G. (Director). (2005). The Hitchhiker's Guide to the Galaxy [Movie]. Touchstone Pictures.

Jeneut, J.P. (Director). 1997. Alien: Resurrection [Movie]. Twentieth Century Fox.

Jung, C.G. (2002). Flying saucers. A modern myth of things seen in the sky. Routledge.

Kirby, D. A. (2003). Scientists on the set: science consultants and the communication of science in visual fiction. Public Understanding of Science 12 (3), 261-78. https://doi.org/10.1177/0963662503123005.

Kracher, A. (2006). Meta-humans and metanoia: the moral dimension of extreterrestrials. Zygon, 41 (2), 329-46. https://doi.org/10.1111/j.14679744.2005.00741.x

Lempert, W. (2014). Decolonizing encounters of the third kind: alternative futuring in native science fiction film. Visual Anthropology Review, 30 (2), 164-76. https://doi.org/10.1111/var.12046 
Lévinas, E. (1993). Entre nosotros. Ensayos para pensar en el otro [Amongst ourselves. Essays to think on the other]. Pre-textos.

Lovecraft, H.P. [1927]. Supernatural horror in literature. (2009, Oct, 20) http://www.hplovecraft.com/writings/texts/essays/shil.aspx

Marez, C. (2007). Aliens and Indians: science fiction, prophetic photography and near-future visions. Journal of Visual Culture, 6 (2), 255-73. https://doi. org/10.1177/1470412907078568

Martos-Núñez, E., and Martos-García, A. (2015). Remediación y patrones narratológicos de las historias de aliens en la cultura mediática. Palabra Clave 18 (3), 788-814. https://doi.org/10.5294/pacla.2015.18.3.7

Mayer, S. (2017). Girl power: Back to the future of feminist science fiction with into the forest and arrival. Film Quarterly, 70(3), 32-42. https://doi. org/10.1525/FQ.2017.70.3.32

Méliès, G. (Producer and Director). (1902). A Trip to the moon [Movie]. Star-Film.

Merton, R. (2002). Teoría y Estructura Sociales [Theory and Social Structure]. Fondo de Cultura Económica.

Miller, R. (2017). Aliens. Past, Present, Future. London: Watkins.

Mills, J. (2003). Lacan on Paranoiac Knowledge. Psychoanalytic Psychology, 20 (1), 30-51. https://doi.org/10.1037/0736-9735.20.1.30

Moffitt, J. (2006). Alienígenas. IConografía de los extraterrestres. Siruela.

Moulton Howe, L.. (2016). The Rosswell Files. In Ancient Aliens. The Official Companion Book. K. Burns, editor, pp.163-76. HarperCollins. 
Narusawa, S, Aota, T, and Kishimoto, R. (2018). Which colors would extraterrestrial civilizations use to transmit signals?: The 'magic wavelengths' for optical seti. New Astronomy, 60,61-64. https://doi.org/10.1016/j. newast.2017.10.003.

Patchett, T. \& Fusco, P. (Creators). (1986). Alf [TV series]. NBC.

Peters, J. D. (1999). Speaking into the air: a history of the idea of communication. University of Chicago Press.

Peters, T. (2018). Does extra-terrestrial life have intrinsic value? An exploration in responsibility ethics. International Journal of Astrobiology, 1-7. https://doi.org/10.1017/S147355041700057X

Pheasant-Kelly, F. (2016). Towards a structure of feeling: abjection and allegories of disease in science fiction 'mutation' films. Medical Humanities 42 (4), 238-45. https://doi.org/10.1136/medhum-2016-010970

Pincio, T. (2009). Aliens ¿Hay alguien ahí afuera? 451 Ediciones.

Plato. (1997a). Republic. Plato Complete Works, edited by J. M. Cooper. Hackett Publishing Company.

Plato. (1997b). Thaetetus. Plato Complete Works, edited by J. M. Cooper, pp.157-234. Hackett Publishing Company.

Ricoeur, P. (2005). The Course of recognition. Harvard University Press.

Roncallo-Dow, S., Goyeneche-Gómez, E. \& Uribe-Jongbloed, E. (2016). Volver a los clásicos: Teorías de la comunicación y cultura pop [Back to the classics: Communication Theory and Pop Culture]. Uniediciones.

Rutherford, A. (2017). It Came from beyond the silver screen! aliens in the movies. In Aliens. The world's leading scientists on the search for extraterrestrial life, edited by Jim Al-Khalili, pp.169-77. Picador. 
Schofield Clark, L. (2005). From Angels to Aliens. Teenagers, the media, and the supernatural. Oxford University Press

Scolari, C. (2005). No pasarán. Las invasiones alienígenas de Wells a Spielberg. Páginas de espuma.

Scott, R. (Director). 2011 [1979]. Alien (DVD). Twentieth Century Fox.

Maylam, T. (Director). (1992). Split Second [Movie]. Challenge Film Corporation.

Sutton, L. (2016). Aliens are just like us: personal names in the legion of superheroes. Names. A Journal of Onomastics 64 (2), 109-19. https://doi.org/10 $.1080 / 00277738.2016 .1159446$

Spielberg, S. (Director). (1982). E.T. The extra-terrestrial [Movie]. Universal Studios and Amblin Entertainment.

Szendy, P. (2013). Kant in the land of extra-terrestrials: cosmopolitical philosofictions. Fordham University Press.

Thomas, W. (2005). La definición de la situación [Social Definition of the Situation]. Cuadernos de Información y Comunicación, 10, 27-32.

Tromly, L. (2017). Race, Citizenship, and the Politics of Alien Abduction; Or, Why aliens do not abduct Asian americans. The Journal of Popular Culture 50 (2), 276-92. https://doi.org/10.1111/jpcu.12545

Van Veuren, M. J. (2012). Tooth and nail: anxious bodies in Neill Blomkamp's District 9. Critical Arts 26 (4), 570-86. https://doi.org/10.1080/02560046. 2012.723847

Veracini, L. (2011). District 9 and Avatar: Science Fiction and Settler Colonialism. Journal of Intercultural Studies 32 (4), 355-67. https://doi.org/10.1080/072 56868.2011 .584614

Verhoeven, P. (Director). (1997). Starship Troopers [Movie]. TriStar Pictures. 
Villeneuve, D. (Director). (2016). Arrival [Movie]. Film Nation Entertainment.

Von Däniken, E. (1968). Erinnerungen an die Zukunft: Ungelöste Rätsel der Vergangenheit. Econ-Verlag.

Von Däniken, E. (2016). Ezekiel's wheel. In Ancient Aliens. The official companion book, K. Burns (Ed.), pp.1-10. HarperCollins.

Wagner, K. B. (2015). District 9, race and neoliberalism in PostApartheid Johannesburg." Race \& Class 57 (2), 43-59. https://doi. org/10.1177/0306396815595800

Washbourne, K. (2015). The outer limits of otherness: ideologies of human translation in speculative fiction. Translation Studies 8 (3), 284-301. https:// doi.org/10.1080/14781700.2014.931817

Wise, R. (Director). (1951). The day the earth stood still [Movie]. Brandywine production \& 20th Century Fox.

Wise, R. (Director). (1979). Star Trek: The Motion Picture [Movie]. Paramount Pictures.

Wittgenstein, L. (2009). Philosophical Investigations. Wiley-Blackwell.

Wolf, T (Creator). (1985). Thundercats. [TV serie]. Rankin/Bass Productions.

How to cite: : Roncallo-Dow, S; Uribe-Jongbloed, E; \& Aguilar-Rodríguez, D. (2021). We come in Peace! (Well, do they?): Human Communicative Fears in Films of an Extra-terrestrial Nature. Revista KEPES, 18(23), 273-313. https://doi.org/10.17151/kepes.2021.18.23.10 
Wittgenstein, Ludwig. 2009. Philosophical Investigations. Oxford: Wiley-Blackwell.

\begin{tabular}{|c|c|c|c|c|c|}
\hline Title & Year & Country & Relation to Humanity & Alien characters & $\begin{array}{l}\text { Type of } \\
\text { Communication }\end{array}$ \\
\hline Alien Agent & 2007 & Canada & $\begin{array}{l}\text { Conflict due to } \\
\text { imminent invasion }\end{array}$ & Human-like & Conflict \\
\hline $\begin{array}{l}\text { Decoys 2: Alien } \\
\text { Seduction }\end{array}$ & 2007 & Canada & Threat to human life & Body snatcher & Conflict \\
\hline $\begin{array}{l}\text { Aliens vs. Predator: } \\
\text { Requiem }\end{array}$ & 2007 & USA & Threat to human life & $\begin{array}{l}\text { Hostile Alien life } \\
\text { form }\end{array}$ & Conflict \\
\hline AVH: Alien vs Hunter & 2007 & USA & Threat to human life & $\begin{array}{l}\text { Hostile Alien life } \\
\text { form }\end{array}$ & Conflict \\
\hline Battle for Terra & 2007 & USA & $\begin{array}{l}\text { Conflict due to } \\
\text { imminent invasion / } \\
\text { Humans are invading } \\
\text { another world }\end{array}$ & Humanoids & Conflict \\
\hline $\begin{array}{l}\text { Ben 10: Race Against } \\
\text { Time }\end{array}$ & 2007 & USA & Threat to human life & $\begin{array}{l}\text { All sorts of Alien } \\
\text { forms }\end{array}$ & Conflict \\
\hline $\begin{array}{l}\text { Fantastic Four: Rise of } \\
\text { the Silver Surfer }\end{array}$ & 2007 & USA & Threat to human life & Humanoids & Conflict \\
\hline $\begin{array}{l}\text { Futurama: Bender's Big } \\
\text { Score }\end{array}$ & 2007 & USA & Human stupidity & $\begin{array}{l}\text { All sorts of Alien } \\
\text { forms }\end{array}$ & Interaction \\
\hline Illegal Aliens & 2007 & USA & Threat to human life & Body snatcher & Conflict \\
\hline Night Skies & 2007 & USA & Alien abduction & $\begin{array}{l}\text { Hostile Alien life } \\
\text { form }\end{array}$ & No Interaction \\
\hline $\begin{array}{l}\text { Species - The } \\
\text { Awakening }\end{array}$ & 2007 & USA & Threat to human life & Body snatcher & Conflict \\
\hline Spider-Man 3 & 2007 & USA & Threat to human life & $\begin{array}{l}\text { Hostile Alien life } \\
\text { form }\end{array}$ & Conflict \\
\hline The Invasion & 2007 & USA & $\begin{array}{l}\text { Conflict due to } \\
\text { imminent invasion }\end{array}$ & Body snatcher & Conflict \\
\hline
\end{tabular}


Roncallo-Dow, S; Uribe-Jongbloed, E; \& Aguilar-Rodríguez, D. / We come in Peace! (Well, do they?): Human Communicative Fears in Films of an Extra-terrestrial Nature

\begin{tabular}{|c|c|c|c|c|c|}
\hline Title & Year & Country & Relation to Humanity & Alien characters & $\begin{array}{l}\text { Type of } \\
\text { Communication }\end{array}$ \\
\hline Transformers & 2007 & USA & $\begin{array}{l}\text { Imminent invasion } \\
\text { stopped by friendly } \\
\text { alien }\end{array}$ & Alien life form & Conflict \\
\hline Transmorphers & 2007 & USA & $\begin{array}{l}\text { Imminent invasion } \\
\text { stopped by friendly } \\
\text { alien }\end{array}$ & Alien life form & Conflict \\
\hline Infected & 2008 & Canada & $\begin{array}{l}\text { Conflict due to } \\
\text { imminent invasion }\end{array}$ & $\begin{array}{l}\text { Human-like / Body } \\
\text { snatcher }\end{array}$ & Conflict \\
\hline CJ7 & 2008 & $\begin{array}{l}\text { Hong Kong } \\
\text { - China }\end{array}$ & Solidarity & $\begin{array}{l}\text { Friendly Alien life } \\
\text { form }\end{array}$ & Interaction \\
\hline $\begin{array}{l}\text { The Monster X Strikes } \\
\text { Back/Attack the G8 } \\
\text { Summit }\end{array}$ & 2008 & Japan & Threat to human life & $\begin{array}{l}\text { Hostile Alien life } \\
\text { form }\end{array}$ & Conflict \\
\hline Alien Raiders & 2008 & USA & Threat to human life & $\begin{array}{l}\text { Hostile Alien life } \\
\text { form }\end{array}$ & Conflict \\
\hline Christmas on Mars & 2008 & USA & Solidarity & Human-like & Interaction \\
\hline Cloverfield & 2008 & USA & $\begin{array}{l}\text { Conflict due to } \\
\text { imminent invasion }\end{array}$ & $\begin{array}{l}\text { Hostile Alien life } \\
\text { form }\end{array}$ & Conflict \\
\hline $\begin{array}{l}\text { Futurama: The Beast } \\
\text { with a Billion Backs }\end{array}$ & 2008 & USA & Human stupidity & $\begin{array}{l}\text { All sorts of Alien } \\
\text { forms }\end{array}$ & Interaction \\
\hline Meet Dave & 2008 & USA & Exploring human life & Body snatcher & Interaction \\
\hline Outlander & 2008 & USA & Threat to human life & $\begin{array}{l}\text { Hostile Alien life } \\
\text { form }\end{array}$ & Conflict \\
\hline $\begin{array}{l}\text { Star Wars: The Clone } \\
\text { Wars }\end{array}$ & 2008 & USA & Intergalactic war & $\begin{array}{l}\text { All sorts of Alien } \\
\text { forms }\end{array}$ & $\begin{array}{l}\text { Interaction - } \\
\text { Conflict }\end{array}$ \\
\hline $\begin{array}{l}\text { Starship Troopers 3: } \\
\text { Marauder }\end{array}$ & 2008 & USA & $\begin{array}{l}\text { Conflict due to } \\
\text { imminent invasion }\end{array}$ & $\begin{array}{l}\text { Hostile Alien life } \\
\text { form }\end{array}$ & Conflict \\
\hline $\begin{array}{l}\text { The Day the Earth Stood } \\
\text { Still }\end{array}$ & 2008 & USA & $\begin{array}{l}\text { Conflict due to } \\
\text { imminent invasion }\end{array}$ & Human-like & Conflict \\
\hline $\begin{array}{l}\text { War of the Worlds 2: } \\
\text { The Next Wave }\end{array}$ & 2008 & USA & $\begin{array}{l}\text { Conflict due to } \\
\text { imminent invasion }\end{array}$ & $\begin{array}{l}\text { Hostile Alien life } \\
\text { form }\end{array}$ & Conflict \\
\hline
\end{tabular}




\begin{tabular}{|c|c|c|c|c|c|}
\hline Title & Year & Country & Relation to Humanity & Alien characters & $\begin{array}{l}\text { Type of } \\
\text { Communication }\end{array}$ \\
\hline Pandorum & 2009 & $\begin{array}{l}\text { Germany } \\
\text { - UK }\end{array}$ & Threat to human life & Humanoids & Conflict \\
\hline Under the Mountain & 2009 & $\begin{array}{l}\text { New } \\
\text { Zealand }\end{array}$ & Threat to human life & Human-like & Conflict \\
\hline District 9 & 2009 & South Africa & $\begin{array}{l}\text { Aliens discriminated } \\
\text { by humans }\end{array}$ & Alien life form & Interaction \\
\hline Alien Trespass & 2009 & USA & $\begin{array}{l}\text { Conflict due to } \\
\text { imminent invasion }\end{array}$ & Interaction & $\begin{array}{l}\text { Interaction } \\
\text { through human } \\
\text { body }\end{array}$ \\
\hline Aliens in the Attic & 2009 & USA & $\begin{array}{l}\text { Conflict due to } \\
\text { imminent invasion }\end{array}$ & $\begin{array}{l}\text { Hostile Alien life } \\
\text { form }\end{array}$ & $\begin{array}{l}\text { Interaction with } \\
\text { a humanized } \\
\text { character }\end{array}$ \\
\hline Avatar & 2009 & USA & $\begin{array}{l}\text { Conflict due to } \\
\text { imminent invasion / } \\
\text { Humans are invading } \\
\text { another world }\end{array}$ & Humanoids & $\begin{array}{l}\text { Interaction with } \\
\text { a humanized } \\
\text { character }\end{array}$ \\
\hline Ben 10: Alien Swarm & 2009 & USA & Threat to human life & $\begin{array}{l}\text { All sorts of Alien } \\
\text { forms }\end{array}$ & Conflict \\
\hline Dragonball Evolution & 2009 & USA & Threat to human life & Alien life form & Conflict \\
\hline Knowing & 2009 & USA & Threat to human life & $\begin{array}{l}\text { Unknown alien } \\
\text { force }\end{array}$ & No Interaction \\
\hline Monsters vs. Aliens & 2009 & USA & Threat to human life & $\begin{array}{l}\text { Humanized } \\
\text { monsters protect } \\
\text { humanity from } \\
\text { hostile Alien life } \\
\text { form }\end{array}$ & $\begin{array}{l}\text { Interaction - } \\
\text { Conflict }\end{array}$ \\
\hline $\begin{array}{l}\text { Mutant Swinger from } \\
\text { Mars }\end{array}$ & 2009 & USA & Threat to human life & Humanoids & $\begin{array}{l}\text { Interaction - } \\
\text { Conflict }\end{array}$ \\
\hline Planet 51 & 2009 & USA & Fear to humans & Humanoids & Interaction \\
\hline Princess of Mars & 2009 & USA & $\begin{array}{l}\text { Threat to leading role's } \\
\text { life }\end{array}$ & Human-like & $\begin{array}{l}\text { Interaction - } \\
\text { Conflict }\end{array}$ \\
\hline Race to Witch Mountain & 2009 & USA & $\begin{array}{l}\text { Imminent invasion } \\
\text { stopped by friendly } \\
\text { alien }\end{array}$ & Human-like & Interaction \\
\hline
\end{tabular}


Roncallo-Dow, S; Uribe-Jongbloed, E; \& Aguilar-Rodríguez, D. / We come in Peace! (Well, do they?): Human Communicative Fears in Films of an Extra-terrestrial Nature

\begin{tabular}{|c|c|c|c|c|c|}
\hline Title & Year & Country & Relation to Humanity & Alien characters & $\begin{array}{l}\text { Type of } \\
\text { Communication }\end{array}$ \\
\hline Star Trek & 2009 & USA & Intergalactic war & $\begin{array}{l}\text { All sorts of Alien } \\
\text { forms }\end{array}$ & $\begin{array}{l}\text { Interaction - } \\
\text { Conflict }\end{array}$ \\
\hline The Fourth Kind & 2009 & USA & Abduction & $\begin{array}{l}\text { Unknown alien } \\
\text { force }\end{array}$ & No Interaction \\
\hline $\begin{array}{l}\text { Transformers: Revenge } \\
\text { of the Fallen }\end{array}$ & 2009 & USA & $\begin{array}{l}\text { Imminent invasion } \\
\text { stopped by friendly } \\
\text { alien }\end{array}$ & Alien life form & $\begin{array}{l}\text { Interaction - } \\
\text { Conflict }\end{array}$ \\
\hline $\begin{array}{l}\text { Transmorphers: Fall } \\
\text { of Man }\end{array}$ & 2009 & USA & $\begin{array}{l}\text { Imminent invasion } \\
\text { stopped by friendly } \\
\text { alien }\end{array}$ & Alien life form & $\begin{array}{l}\text { Interaction - } \\
\text { Conflict }\end{array}$ \\
\hline $\begin{array}{l}\text { Mobile Suit Gundam } 00 \\
\text { the Movie: A Wakening } \\
\text { of the Trailblazer }\end{array}$ & 2010 & Japan & $\begin{array}{l}\text { Conflict due to } \\
\text { imminent invasion }\end{array}$ & Alien life form & $\begin{array}{l}\text { Interaction - } \\
\text { Conflict }\end{array}$ \\
\hline Alien vs Ninja & 2010 & USA & Threat to human life & Alien life form & Conflict \\
\hline Darkening Sky & 2010 & USA & Abduction & Body snatcher & $\begin{array}{l}\text { Interaction } \\
\text { through human } \\
\text { body }\end{array}$ \\
\hline Megamind & 2010 & USA & Threat to human life & Humanoids & $\begin{array}{l}\text { Interaction - } \\
\text { Conflict }\end{array}$ \\
\hline Monsters & 2010 & UK & $\begin{array}{l}\text { Conflict due to } \\
\text { imminent invasion }\end{array}$ & $\begin{array}{l}\text { Hostile Alien life } \\
\text { form }\end{array}$ & Conflict \\
\hline Predators & 2010 & USA & Threat to human life & $\begin{array}{l}\text { Hostile Alien life } \\
\text { form }\end{array}$ & Conflict \\
\hline Skyline & 2010 & USA & $\begin{array}{l}\text { Conflict due to } \\
\text { imminent invasion }\end{array}$ & $\begin{array}{l}\text { Hostile Alien life } \\
\text { form }\end{array}$ & Conflict \\
\hline $\begin{array}{l}\text { Welcome to the Space } \\
\text { Show }\end{array}$ & 2010 & Japan & Friendship & Alien life form & Interaction \\
\hline Iron Invader & 2011 & Canada & Threat to human life & Alien life form & Conflict \\
\hline 6 Days on Earth & 2011 & Italy & Abduction & Alien life form & $\begin{array}{l}\text { Interaction } \\
\text { through human } \\
\text { body }\end{array}$ \\
\hline Paul & 2011 & UK - USA & Friendship & Alien life form & Interaction \\
\hline
\end{tabular}




\begin{tabular}{|c|c|c|c|c|c|}
\hline Title & Year & Country & Relation to Humanity & Alien characters & $\begin{array}{l}\text { Type of } \\
\text { Communication }\end{array}$ \\
\hline Aliens vs. Avatars & 2011 & USA & Threat to human life & Humanoids & $\begin{array}{l}\text { Interaction - } \\
\text { Conflict }\end{array}$ \\
\hline Apollo 18 & 2011 & USA & Threat to human life & $\begin{array}{l}\text { Hostile Alien life } \\
\text { form }\end{array}$ & Conflict \\
\hline Attack the Block & 2011 & UK & $\begin{array}{l}\text { Conflict due to } \\
\text { imminent invasion }\end{array}$ & $\begin{array}{l}\text { Hostile Alien life } \\
\text { form }\end{array}$ & Conflict \\
\hline Battle: Los Angeles & 2011 & USA & $\begin{array}{l}\text { Conflict due to } \\
\text { imminent invasion }\end{array}$ & $\begin{array}{l}\text { Hostile Alien life } \\
\text { form }\end{array}$ & Conflict \\
\hline Cowboys \& Aliens & 2011 & USA & $\begin{array}{l}\text { Conflict due to } \\
\text { imminent invasion }\end{array}$ & $\begin{array}{l}\text { Hostile Alien life } \\
\text { form }\end{array}$ & Conflict \\
\hline Green Lantern & 2011 & USA & Intergalactic war & $\begin{array}{l}\text { All sorts of Alien } \\
\text { forms }\end{array}$ & $\begin{array}{l}\text { Interaction - } \\
\text { Conflict }\end{array}$ \\
\hline I Am Number Four & 2011 & USA & $\begin{array}{l}\text { Imminent invasion } \\
\text { stopped by friendly } \\
\text { alien }\end{array}$ & Human-like & $\begin{array}{l}\text { Interaction - } \\
\text { Conflict }\end{array}$ \\
\hline Mars Needs Moms & 2011 & USA & Abduction & $\begin{array}{l}\text { Hostile Alien life } \\
\text { form }\end{array}$ & Conflict \\
\hline Super 8 & 2011 & USA & Threat to human life & $\begin{array}{l}\text { Hostile Alien life } \\
\text { form }\end{array}$ & Conflict \\
\hline The Thing & 2011 & USA & Threat to human life & Alien life form & Conflict \\
\hline Thor & 2011 & USA & $\begin{array}{l}\text { Imminent invasion } \\
\text { stopped by friendly } \\
\text { alien }\end{array}$ & Human-like & $\begin{array}{l}\text { Interaction - } \\
\text { Conflict }\end{array}$ \\
\hline $\begin{array}{l}\text { Transformers: Dark of } \\
\text { the Moon }\end{array}$ & 2011 & USA & $\begin{array}{l}\text { Imminent invasion } \\
\text { stopped by friendly } \\
\text { alien }\end{array}$ & Alien life form & $\begin{array}{l}\text { Interaction - } \\
\text { Conflict }\end{array}$ \\
\hline The Darkest Hour & 2011 & USA-Russia & $\begin{array}{l}\text { Conflict due to } \\
\text { imminent invasion }\end{array}$ & $\begin{array}{l}\text { Hostile Alien life } \\
\text { form }\end{array}$ & Conflict \\
\hline Joker & 2012 & India & Aliens communicating & Alien life form & Interaction \\
\hline Grabbers & 2012 & Ireland - UK & Threat to human life & $\begin{array}{l}\text { Hostile Alien life } \\
\text { form }\end{array}$ & Conflict \\
\hline
\end{tabular}


Roncallo-Dow, S; Uribe-Jongbloed, E; \& Aguilar-Rodríguez, D. / We come in Peace! (Well, do they?): Human Communicative Fears in Films of an Extra-terrestrial Nature

\begin{tabular}{|c|c|c|c|c|c|}
\hline Title & Year & Country & Relation to Humanity & Alien characters & $\begin{array}{l}\text { Type of } \\
\text { Communication }\end{array}$ \\
\hline U.F.O. & 2012 & UK & $\begin{array}{l}\text { Conflict due to } \\
\text { imminent invasion }\end{array}$ & $\begin{array}{l}\text { Hostile Alien life } \\
\text { form }\end{array}$ & Conflict \\
\hline Alien Origin & 2012 & USA & Threat to human life & $\begin{array}{l}\text { Hostile Alien life } \\
\text { form }\end{array}$ & Conflict \\
\hline Battleship & 2012 & USA & $\begin{array}{l}\text { Conflict due to } \\
\text { imminent invasion }\end{array}$ & $\begin{array}{l}\text { Hostile Alien life } \\
\text { form }\end{array}$ & Conflict \\
\hline $\begin{array}{l}\text { Ben 10: Destroy All } \\
\text { Aliens }\end{array}$ & 2012 & USA & Threat to human life & $\begin{array}{l}\text { All sorts of Alien } \\
\text { forms }\end{array}$ & Conflict \\
\hline John Carter & 2012 & USA & Threat to human life & Human-like & $\begin{array}{l}\text { Interaction - } \\
\text { Conflict }\end{array}$ \\
\hline Men in Black 3 & 2012 & USA & Threat to human life & $\begin{array}{l}\text { All sorts of Alien } \\
\text { forms }\end{array}$ & $\begin{array}{l}\text { Interaction - } \\
\text { Conflict }\end{array}$ \\
\hline Prometheus & 2012 & USA & Threat to human life & $\begin{array}{l}\text { Hostile Alien life } \\
\text { form }\end{array}$ & Conflict \\
\hline The Avengers & 2012 & USA & $\begin{array}{l}\text { Imminent invasion } \\
\text { stopped by friendly } \\
\text { alien }\end{array}$ & $\begin{array}{l}\text { Hostile Alien life } \\
\text { form }\end{array}$ & $\begin{array}{l}\text { Interaction - } \\
\text { Conflict }\end{array}$ \\
\hline The Watch & 2012 & USA & $\begin{array}{l}\text { Imminent invasion } \\
\text { stopped by friendly } \\
\text { alien }\end{array}$ & $\begin{array}{l}\text { Hostile Alien life } \\
\text { form }\end{array}$ & $\begin{array}{l}\text { Interaction - } \\
\text { Conflict }\end{array}$ \\
\hline $\begin{array}{l}\text { War of the Worlds - The } \\
\text { True Story }\end{array}$ & 2012 & USA & $\begin{array}{l}\text { Conflict due to } \\
\text { imminent invasion }\end{array}$ & $\begin{array}{l}\text { Hostile Alien life } \\
\text { form }\end{array}$ & Conflict \\
\hline Krrish 3 & 2013 & India & Threat to human life & $\begin{array}{l}\text { Hostile Alien life } \\
\text { form }\end{array}$ & $\begin{array}{l}\text { Interaction - } \\
\text { Conflict }\end{array}$ \\
\hline The World's End & 2013 & UK-USA & $\begin{array}{l}\text { Conflict due to } \\
\text { imminent invasion }\end{array}$ & Body snatcher & $\begin{array}{l}\text { Interaction - } \\
\text { Conflict }\end{array}$ \\
\hline After Earth & 2013 & USA & Threat to human life & $\begin{array}{l}\text { All sorts of Alien } \\
\text { forms }\end{array}$ & Conflict \\
\hline Almost Human & 2013 & USA & Abduction & Body snatcher & $\begin{array}{l}\text { Interaction - } \\
\text { Conflict }\end{array}$ \\
\hline Dark Skies & 2013 & USA & Abduction & $\begin{array}{l}\text { Hostile Alien life } \\
\text { form }\end{array}$ & Conflict \\
\hline
\end{tabular}




\begin{tabular}{|c|c|c|c|c|c|}
\hline Title & Year & Country & Relation to Humanity & Alien characters & $\begin{array}{l}\text { Type of } \\
\text { Communication }\end{array}$ \\
\hline Ender's Game & 2013 & USA & $\begin{array}{l}\text { Conflict due to } \\
\text { imminent invasion }\end{array}$ & $\begin{array}{l}\text { Hostile Alien life } \\
\text { form }\end{array}$ & Conflict \\
\hline Europa Report & 2013 & USA & $\begin{array}{l}\text { Humans looking for } \\
\text { E.T: life in outer space }\end{array}$ & $\begin{array}{l}\text { Hostile Alien life } \\
\text { form }\end{array}$ & Conflict \\
\hline Man of Steel & 2013 & USA & $\begin{array}{l}\text { Imminent invasion } \\
\text { stopped by friendly } \\
\text { alien }\end{array}$ & Human-like & $\begin{array}{l}\text { Interaction - } \\
\text { Conflict }\end{array}$ \\
\hline Oblivion & 2013 & USA & Threat to human life & Human-like & $\begin{array}{l}\text { Interaction - } \\
\text { Conflict }\end{array}$ \\
\hline Pacific Rim & 2013 & USA & $\begin{array}{l}\text { Ongoing war with } \\
\text { aliens }\end{array}$ & $\begin{array}{l}\text { Hostile Alien life } \\
\text { form }\end{array}$ & Conflict \\
\hline Star Trek Into Darkness & 2013 & USA & Intergalactic war & $\begin{array}{l}\text { All sorts of Alien } \\
\text { forms }\end{array}$ & $\begin{array}{l}\text { Interaction - } \\
\text { Conflict }\end{array}$ \\
\hline The Host & 2013 & USA & Threat to human life & Body snatcher & Conflict \\
\hline Thor: The Dark World & 2013 & USA & $\begin{array}{l}\text { Imminent invasion } \\
\text { stopped by friendly } \\
\text { alien }\end{array}$ & Human-like & $\begin{array}{l}\text { Interaction - } \\
\text { Conflict }\end{array}$ \\
\hline Unaware & 2013 & USA & Threat to human life & $\begin{array}{l}\text { Hostile Alien life } \\
\text { form }\end{array}$ & Conflict \\
\hline Under the Skin & 2013 & $\begin{array}{l}\text { USA, UK } \\
\text { Switzerland }\end{array}$ & Threat to human life & Human-like & Seduction \\
\hline $\mathrm{V} / \mathrm{H} / \mathrm{S} / 2$ & 2013 & $\begin{array}{l}\text { USA- } \\
\text { Canada- } \\
\text { Indonesia }\end{array}$ & Threat to human life & $\begin{array}{l}\text { Hostile Alien life } \\
\text { form }\end{array}$ & Conflict \\
\hline $\begin{array}{l}\text { Monsters: Dark } \\
\text { Continent }\end{array}$ & 2014 & UK & Threat to human life & $\begin{array}{l}\text { Hostile Alien life } \\
\text { form }\end{array}$ & Conflict \\
\hline Alien Abduction & 2014 & USA & Abduction & $\begin{array}{l}\text { Unknown alien } \\
\text { force }\end{array}$ & Conflict \\
\hline $\begin{array}{l}\text { Angry Video Game } \\
\text { Nerd: The Movie }\end{array}$ & 2014 & USA & Threat to human life & $\begin{array}{l}\text { Unknown alien } \\
\text { force }\end{array}$ & Conflict \\
\hline Earth to Echo & 2014 & USA & Solidarity & $\begin{array}{l}\text { Friendly Alien life } \\
\text { form }\end{array}$ & Friendship \\
\hline
\end{tabular}


Roncallo-Dow, S; Uribe-Jongbloed, E; \& Aguilar-Rodríguez, D. / We come in Peace! (Well, do they?): Human Communicative Fears in Films of an Extra-terrestrial Nature

\begin{tabular}{|c|c|c|c|c|c|}
\hline Title & Year & Country & Relation to Humanity & Alien characters & $\begin{array}{l}\text { Type of } \\
\text { Communication }\end{array}$ \\
\hline Edge of Tomorrow & 2014 & USA & $\begin{array}{l}\text { Ongoing war with } \\
\text { aliens }\end{array}$ & $\begin{array}{l}\text { Hostile Alien life } \\
\text { form }\end{array}$ & Conflict \\
\hline Extraterrestrial & 2014 & USA & Threat to human life & $\begin{array}{l}\text { Hostile Alien life } \\
\text { form }\end{array}$ & Conflict \\
\hline Guardians of the Galaxy & 2014 & USA & Intergalactic war & $\begin{array}{l}\text { All sorts of Alien } \\
\text { forms }\end{array}$ & Conflict \\
\hline Honeymoon & 2014 & USA & Abduction & Body snatcher & Conflict \\
\hline The Signal & 2014 & USA & Abduction & Body snatcher & Conflict \\
\hline $\begin{array}{l}\text { Transformers: Age of } \\
\text { Extinction }\end{array}$ & 2014 & USA & $\begin{array}{l}\text { Imminent invasion } \\
\text { stopped by friendly } \\
\text { alien }\end{array}$ & Alien life form & $\begin{array}{l}\text { Interaction - } \\
\text { Conflict }\end{array}$ \\
\hline Area 51 & 2015 & USA & Abduction & $\begin{array}{l}\text { Unknown alien } \\
\text { force }\end{array}$ & Conflict \\
\hline Avengers: Age of Ultron & 2015 & USA & $\begin{array}{l}\text { Imminent invasion } \\
\text { stopped by friendly } \\
\text { alien }\end{array}$ & $\begin{array}{l}\text { Hostile Alien life } \\
\text { form }\end{array}$ & $\begin{array}{l}\text { Interaction - } \\
\text { Conflict }\end{array}$ \\
\hline Freaks of Nature & 2015 & USA & $\begin{array}{l}\text { Conflict due to } \\
\text { imminent invasion }\end{array}$ & $\begin{array}{l}\text { Hostile Alien life } \\
\text { form }\end{array}$ & $\begin{array}{l}\text { Interaction - } \\
\text { Conflict }\end{array}$ \\
\hline Home & 2015 & USA & Solidarity & $\begin{array}{l}\text { Friendly Alien life } \\
\text { form }\end{array}$ & Friendship \\
\hline Jupiter Ascending & 2015 & USA & Intergalactic war & $\begin{array}{l}\text { Hostile Alien life } \\
\text { form }\end{array}$ & $\begin{array}{l}\text { Interaction - } \\
\text { Conflict }\end{array}$ \\
\hline Pixels & 2015 & USA & $\begin{array}{l}\text { Conflict due to } \\
\text { imminent invasion }\end{array}$ & $\begin{array}{l}\text { Hostile Alien life } \\
\text { form }\end{array}$ & $\begin{array}{l}\text { Interaction - } \\
\text { Conflict }\end{array}$ \\
\hline $\begin{array}{l}\text { Star Wars: Episode VII - } \\
\text { The Force Awakens }\end{array}$ & 2015 & USA & Intergalactic war & $\begin{array}{l}\text { All sorts of Alien } \\
\text { forms }\end{array}$ & $\begin{array}{l}\text { Interaction - } \\
\text { Conflict }\end{array}$ \\
\hline The Phoenix Incident & 2015 & USA & Abduction & $\begin{array}{l}\text { Unknown alien } \\
\text { force }\end{array}$ & Conflict \\
\hline 10 Cloverfield Lane & 2016 & USA & $\begin{array}{l}\text { Conflict due to } \\
\text { imminent invasion }\end{array}$ & $\begin{array}{l}\text { Hostile Alien life } \\
\text { form }\end{array}$ & Conflict \\
\hline Arrival & 2016 & USA & $\begin{array}{l}\text { Attempting contact } \\
\text { with Aliens }\end{array}$ & $\begin{array}{l}\text { Unknown alien } \\
\text { force }\end{array}$ & $\begin{array}{l}\text { Interaction - } \\
\text { Conflict }\end{array}$ \\
\hline
\end{tabular}




\begin{tabular}{|c|c|c|c|c|c|}
\hline Title & Year & Country & Relation to Humanity & Alien characters & $\begin{array}{l}\text { Type of } \\
\text { Communication }\end{array}$ \\
\hline $\begin{array}{l}\text { Batman v Superman: } \\
\text { Dawn of Justice }\end{array}$ & 2016 & USA & $\begin{array}{l}\text { Imminent invasion } \\
\text { stopped by friendly } \\
\text { alien }\end{array}$ & Alien life form & $\begin{array}{l}\text { Interaction - } \\
\text { Conflict }\end{array}$ \\
\hline Doctor Strange & 2016 & USA & $\begin{array}{l}\text { Conflict due to } \\
\text { imminent invasion }\end{array}$ & $\begin{array}{l}\text { Unknown alien } \\
\text { force }\end{array}$ & $\begin{array}{l}\text { Interaction - } \\
\text { Conflict }\end{array}$ \\
\hline $\begin{array}{l}\text { Independence Day: } \\
\text { Resurgence }\end{array}$ & 2016 & USA & $\begin{array}{l}\text { Conflict due to } \\
\text { imminent invasion }\end{array}$ & $\begin{array}{l}\text { Hostile Alien life } \\
\text { form }\end{array}$ & Conflict \\
\hline Max Steel & 2016 & USA & Threat to human life & $\begin{array}{l}\text { Friendly Alien life } \\
\text { form }\end{array}$ & $\begin{array}{l}\text { Interaction - } \\
\text { Conflict }\end{array}$ \\
\hline $\begin{array}{l}\text { Rogue One: A Star Wars } \\
\text { Story }\end{array}$ & 2016 & USA & Intergalactic war & $\begin{array}{l}\text { All sorts of Alien } \\
\text { forms }\end{array}$ & $\begin{array}{l}\text { Interaction - } \\
\text { Conflict }\end{array}$ \\
\hline Star Trek Beyond & 2016 & USA & Intergalactic war & $\begin{array}{l}\text { All sorts of Alien } \\
\text { forms }\end{array}$ & $\begin{array}{l}\text { Interaction - } \\
\text { Conflict }\end{array}$ \\
\hline $\begin{array}{l}\text { Teenage Mutant Ninja } \\
\text { Turtles: Out of the } \\
\text { Shadows }\end{array}$ & 2016 & USA & $\begin{array}{l}\text { Imminent invasion } \\
\text { stopped by friendly } \\
\text { alien }\end{array}$ & Alien life form & $\begin{array}{l}\text { Interaction - } \\
\text { Conflict }\end{array}$ \\
\hline The 5th Wave & 2016 & USA & $\begin{array}{l}\text { Ongoing war with } \\
\text { aliens }\end{array}$ & Human-like & $\begin{array}{l}\text { Interaction - } \\
\text { Conflict }\end{array}$ \\
\hline Ratchet \& Clank & 2016 & $\begin{array}{l}\text { USA - } \\
\text { Canada }\end{array}$ & Intergalactic war & Humanoids & $\begin{array}{l}\text { Interaction - } \\
\text { Conflict }\end{array}$ \\
\hline $\begin{array}{l}\text { Valerian and the City of } \\
\text { a Thousand Planets }\end{array}$ & 2017 & France & Intergalactic war & $\begin{array}{l}\text { All sorts of Alien } \\
\text { forms }\end{array}$ & $\begin{array}{l}\text { Interaction - } \\
\text { Conflict }\end{array}$ \\
\hline Alien: Covenant & 2017 & USA & Threat to human life & $\begin{array}{l}\text { Hostile Alien life } \\
\text { form }\end{array}$ & Conflict \\
\hline $\begin{array}{l}\text { Guardians of the Galaxy } \\
\text { Vol. } 2\end{array}$ & 2017 & USA & Intergalactic war & $\begin{array}{l}\text { All sorts of Alien } \\
\text { forms }\end{array}$ & Conflict \\
\hline Justice League & 2017 & USA & $\begin{array}{l}\text { Imminent invasion } \\
\text { stopped by friendly } \\
\text { alien }\end{array}$ & Alien life form & $\begin{array}{l}\text { Interaction - } \\
\text { Conflict }\end{array}$ \\
\hline Life & 2017 & USA & Threat to human life & $\begin{array}{l}\text { Hostile Alien life } \\
\text { form }\end{array}$ & Conflict \\
\hline Phoenix Forgotten & 2017 & USA & Threat to human life & $\begin{array}{l}\text { Hostile Alien life } \\
\text { form }\end{array}$ & Conflict \\
\hline
\end{tabular}


Roncallo-Dow, S; Uribe-Jongbloed, E; \& Aguilar-Rodríguez, D. / We come in Peace! (Well, do they?): Human Communicative Fears in Films of an Extra-terrestrial Nature

\begin{tabular}{llllll}
\hline Title & Year & Country & Relation to Humanity & Alien characters & $\begin{array}{l}\text { Type of } \\
\text { Communication }\end{array}$ \\
\hline Power Rangers & 2017 & USA & $\begin{array}{l}\text { Conflict due to } \\
\text { imminent invasion }\end{array}$ & $\begin{array}{l}\text { All sorts of Alien } \\
\text { forms }\end{array}$ & $\begin{array}{l}\text { Interaction - } \\
\text { Conflict }\end{array}$ \\
\hline $\begin{array}{l}\text { Star Wars: Episode VIII - } \\
\text { The Last Jedi }\end{array}$ & 2017 & USA & Intergalactic war & $\begin{array}{l}\text { All sorts of Alien } \\
\text { forms }\end{array}$ & $\begin{array}{l}\text { Interaction - } \\
\text { Conflict }\end{array}$ \\
\hline $\begin{array}{llll}\text { The Recall } \\
\text { Thor: Ragnarok }\end{array}$ & 2017 & USA & $\begin{array}{l}\text { Alien invasion and } \\
\text { mass abduction }\end{array}$ & $\begin{array}{l}\text { Hostile Alien life } \\
\text { form }\end{array}$ & Conflict \\
\hline $\begin{array}{l}\text { Transformers: The Last } \\
\text { Knight }\end{array}$ & 2017 & USA & $\begin{array}{l}\text { Imminent invasion } \\
\text { stopped by friendly } \\
\text { alien }\end{array}$ & Human-like & $\begin{array}{l}\text { Interaction - } \\
\text { Conflict }\end{array}$ \\
\hline
\end{tabular}

Table 1. List of films with extraterrestrial themes (2007-2017). 